\title{
Biology of the Wasp Polistes (Epicnemius) cinerascens Saussure (Hymenoptera: Vespidae)
}

\author{
Edilberto Giannotti ${ }^{1}$ \\ ${ }^{1}$ Departamento de Zoologia e Centro de Estudos de Insetos Sociais, Instituto \\ de Biociências, Universidade Estadual Paulista, Caixa postal 199, \\ 13506-900, Rio Claro, SP.
}

An. Soc. Entomol. Brasil 26(1): 61-67 (1997)

Biologia da Vespa Polistes (Epicnemius) cinerascens Saussure (Hymenoptera: Vespidae)

\begin{abstract}
RESUMO - Estudos dos ninhos da vespa social Polistes (Epicnemius) cinerascens Saussure apresentaram correlação entre o tamanho do favo e a largura do pedúnculo, bem como com a altura das células e número de gerações produzidas. Foi verificado o tempo de duração do ciclo biológico das colônias (199,3 dias), número de células construídas (102,9) e de adultos produzidos $(94,2)$, além das taxas: 0,5 células/dia, 0,3 adultos/dia e 0,8 adultos/célula, da percentagem de células produtivas/ninho $(55,2 \%)$ e do número de gerações/colônia (até 4). O número de ínstares larvais foi 5 , a taxa de crescimento 1,3 , o tempo de duração dos estágios imaturos foi: ovos $=13,0$ dias, larvas $=23,7$, pupas $-22,2$ e a duração total $=58,6$ dias. A longevidade dos adultos foi 38,3 dias.
\end{abstract}

PALAVRAS-CHAVE: Insecta, ciclo colonial, estágios imaturos, longevidade, tabela de vida.

\begin{abstract}
Studies on nests of the social wasp Polistes (Epicnemius) cinerascens Saussure showed correlation between the size of the comb and thickness of the peduncle, besides of the height of the complete cells and the number of generations produced. The duration of the colony cycle (199.3 days), the number of cells built (102.9) and adults produced (94.2) allowed to establish the rates: 0.5 cells/day, 0.3 adults/day, and 0.8 adults/cell, the $\%$ of productive cells/ nest (55.2), and the number of the generations/colony (up to 4 generations). The number of instars was 5 ; the growing ratio 1.3 ; the duration of the immature stages was eggs $=13.0$ days, larvae $=23.7$, pupae $=22.2$ and total duration $=58.6$ days; and the longevity of adult wasps $=38.3$ days.
\end{abstract}

KEY WORDS: Insecta, colony cycle, immature stages, longevity, life table.

The Neotropical species of Polistes have been poorly studied and the biology of many Brazilian species remains unknown. There are 206 recognized species of Polistes (including the three socially parasitic species of Sulcopolistes) distributed throughout the world (Reeve
1991). According to Richards (1978), there are 84 species in the Americas, 39 of which occur in Brazil.

Polistes (Epicnemius) cinerascens Saussure is a black with yellow markings primitively eusocial wasp which has a broad geogra- 
phic distribution: Argentina, Uruguay, Paraguay, Bolívia, Equador and Brazil (South, Southeast, Central and Northeast regions). The nests were described as small grayish combs, comprising from 5 to 29 cells (complete cells were $18 \mathrm{~mm}$ height and $4.5 \mathrm{~mm}$ wide), with a shining black eccentric peduncle ( $4 \mathrm{~mm}$ long); the cocoon-caps were white or grayish and flat (Richards 1978). In spite of this large occurrence, its biology is unknown.

This study was conducted on the biology of $P$. cinerascens, including the nest architecture, colonial life cycle and productivity, brood development and adult lifespan, to provide a life-table and a survivorship curve of its population.

\section{Material and Methods}

Field studies were carried out in the campus of the Universidade Estadual Paulista, at Rio Claro (2224' S, 47³3' W, altitude $612 \mathrm{~m}$ ), São Paulo State, Southeastem Brazil, from January, 1993 to June, 1994. Seven nests of $P$. cinerascens were mapped daily in different colonial stages of development (pre, postemergence, and decline) with the purpose of studying the development of immature stages and observing the brood loses. Adults were individually marked on the thorax with dots of model airplane enamel for determining their lifespan and for verification of their hierarchical position in the colony. A life-table and a survivorship curve for brood and adult wasps were built, according to Silveira-Neto et al. (1976).

Abandoned nests were collected, dissected and measured (using a caliper) in the following structures: length and thickness (at the widest and narrowest points) of the peduncle, length and width of the comb, height and width (space between two parallel walls) of the complete cells, and the height of the meconial layers in the floor of the cells. Eggs, larvae and pupae of two colonies were fixed in Dietrich solution for $48 \mathrm{~h}$ and preserved in $70 \%$ ethyl alcohol for studies on nest architecture and morphology. Ten immatures of each stage, were measured under stereomicroscopy fit with a reticule, and the number of instars determined according to the width of the cephalic capsules. The approximated foundation date of the colonies $1,2,6,7$, and 8 was estimated by counting the number of meconial layers times the mean duration of the brood development.

\section{Results and Discussion}

The nests of $P$. cinerascens were built under leaves of Sabal maritima (Palmae) $(\mathrm{n}=3)$, Attalea exigua (Palmae) $(\mathrm{n}=1)$, Bambusa metake (Gramineae) $(\mathrm{n}=1)$, Rhododendron indica (Ericaceae) $(\mathrm{n}=1)$, and Agave angustifolia (Amaryllidaceae) $(\mathrm{n}=1)$, at $1.76 \pm 0.37$ $\mathrm{m}$ high from the ground level. The nest eccentric peduncle was $5.9 \pm 1.0 \mathrm{~mm}$ long and its thickness was $1.5 \pm 0.9 \mathrm{~mm}$ at the narrowest point and $2.2 \pm 1.3 \mathrm{~mm}$ at the widest point. The comb measured $52.2 \pm 26.8 \mathrm{~mm}$ at the widest point and $58.3 \pm 30.4 \mathrm{~mm}$ at the longest point. There was a high correlation between the number of cells and peduncle thickness (Spearman coefficient $\mathrm{rs}=0.58$, at the narrowest point, and $\mathrm{rs}=0.84$, at the widest point), confírming that the peduncle was enlarged as the comb grew. The height of the complete cells showed a significant variance $(F=64.5$, $\mathrm{P}<0.001)$ according to the number of generations reared therein. Cells used to rear one generation were $17.3 \pm 1.2 \mathrm{~mm}(\mathrm{n}=83)$ height; 0 two $18.5 \pm 1.3 \mathrm{~mm}(\mathrm{n}=50)$; three $20.2 \pm 1.3 \mathrm{~mm}$ $(\mathrm{n}=34)$; and four generations were $22.5 \pm 2.4$ $\mathrm{mm}(\mathrm{n}=15)$ height. The width of the complete cells did not vary significantly according to the number of generations $(\mathrm{F}=2.3, \mathrm{P}>0.05)$, and the mean width of the cells was $4.8 \pm 0.2$ $(n=182)$. There was a high correlation between height of the meconial layer in the cells and height of the cells ( $r s=0.76$ ), confirming the cells were lengthened according to the number of generations.

In spite of the few number of colonies studied, the dates of foundation and abandonment (Table 1) suggest that the colony 
cycle is asynchronous in relation to months of the year, so that, nest foundations, active nests and abandonments were observed throughout the year. These results agree with those reported by other authors about the colony cycle of social wasps in tropical regions (West-Eberhard 1969, Jeanne 1972, Gobbi \& Zucchi 1980, Simões \& Mecchi 1983, Yamane 1986, Gobbi \& Simões 1988, Giannotti \& Machado 1994c).
Colony 3 was haplometrotic but the Colony 5 had a initial pleometrosis showing from 4 to 8 foundresses during the pre-emergency stage. Colonies 3, 5, 6 and 7 originated by foundresses proceeding from the Colony 2 , and nests were built in the same plant or in the neighborhood (up to $7 \mathrm{~m}$ distant). A number of papers suggested that there is a tendency of sisters to found new nests together and near the parental colony (West-Eberhard 1969,

Table 1. Biological parameters of Polistes cinerascens, obtained in the field at Rio Claro, SP, from January, 1993 to June, 1994.

\begin{tabular}{|c|c|c|c|c|c|c|c|c|c|c|}
\hline Colony & Foundation & $\begin{array}{l}\text { Abandon- } \\
\text { ment }\end{array}$ & $\begin{array}{c}\text { Duration } \\
\text { (days) }\end{array}$ & $\begin{array}{c}\text { Number/ } \\
\text { Cells }\end{array}$ & $\begin{array}{c}\text { Adults } \\
\text { Produced }\end{array}$ & $\begin{array}{l}\text { Cells/ A } \\
\text { Day }\end{array}$ & $\begin{array}{c}\text { Adults/At } \\
\text { Day } \quad C\end{array}$ & $\begin{array}{l}\text { Adults/ } \\
\text { Cells }\end{array}$ & $\begin{array}{c}\text { Productive } \\
\text { Cells }(\%)\end{array}$ & $\begin{array}{c}\text { Number/ } \\
\text { Genera } \\
\text { tions }\end{array}$ \\
\hline 1 & Jun.92 & Mar.93 & 240 & 40 & 42 & 0.2 & 0.2 & 1.1 & 47.5 & 4 \\
\hline 2 & Sep. 92 & Ago.93 & 338 & 234 & 302 & 0.7 & 0.9 & 1.3 & 69.2 & 4 \\
\hline 3 & Jan.93 & May.93 & 208 & 35 & 23 & 0.2 & 0.1 & 0.7 & 48.6 & 2 \\
\hline 4 & $?$ & ? & ? & 38 & 23 & $?$ & $?$ & 0.6 & 42.1 & 2 \\
\hline 5 & Ago.93 & Dec. 94 & 107 & 44 & 22 & 0.4 & 0.2 & 0.5 & 50.0 & 1 \\
\hline 6 & Ago.93 & Jan.94 & 141 & 90 & 53 & 0.6 & 0.4 & 0.6 & 69.8 & 2 \\
\hline 7 & Nov.93 & Feb.94 & 100 & 53 & 25 & 0.5 & 0.3 & 0.5 & 47.2 & 2 \\
\hline 8 & Oct.93 & Jun.94 & 261 & 289 & 264 & 1.1 & 1.0 & 0.9 & 66.8 & 4 \\
\hline $\begin{array}{l}\text { Mean } \\
\text { S.D. }\end{array}$ & & & $\begin{array}{r}199.3 \pm \\
88.1\end{array}$ & $\begin{array}{r}102.9 \pm \\
100.5\end{array}$ & $\begin{array}{r}94.2 \pm \\
117.5\end{array}$ & $\begin{array}{l}0.5 \pm \\
0.3\end{array}$ & $\begin{array}{l}=0.3 \pm \\
0.4\end{array}$ & $\begin{array}{l}0.8 \\
0.3\end{array}$ & 55.2 & \\
\hline
\end{tabular}

Klahn 1979, Shellmann \& Gamboa 1982, Post \& Jeanne 1982, Pfenning et al. 1983, Giannotti \& Mansur 1993). The pre-emergence stage of the Colony 5 lasted 67 days (egg substage 20 days, larval substage 26 days and pupal substage 21 days). The duration of the pre-emergence stage of Polistes versicolor (Olivier) is $86.2 \pm 5.8$ days (Giannotti \& Mansur 1993) and of Polistes lanio lanio (Fabricius) is 76.9 \pm 19.53 days (Giannotti \& Machado 1994c), both longer than that of $P$ cinerascens.

The duration of the colony cycle of $P$. cinerascens was variable, from 100 to 338 days, and the total mean duration was 199.3 days (Table 1). There are three other Brazilian spe- cies of Polistes that were studied regarding lifespans of colonies: P. versicolor 154.8 days (Gobbi \& Zucchi 1985) or 177.0 days (Gobbi et al. 1993), P. simillimus Zikán 277.0 days (Gobbi et al. 1993), and P. lanio lanio 388.0 days (Giannotti \& Machado 1994c). The duration of colony cycle of social wasps is much dependent on climatic conditions, food resources, nest site, and interference of predators and parasitoids. Even so it is possible to detect some intrinsic characteristics that may affect the colony cycle duration. The lifespan of colonies of $P$. cinerascens and $P$ versicolor were similar, produced up to four generations of adults and their nests have an approximate 
Table 2. Life table of brood and workers of Polistes cinerascens from seven colonies studied in Rio Claro, from January, 1993 to June, 1994.

\begin{tabular}{lcccc}
\hline $\begin{array}{l}\text { Stage/age } \\
\text { interval(x) }\end{array}$ & $\begin{array}{c}\text { Number of } \\
\text { survivors(1x) }\end{array}$ & $\begin{array}{c}\text { Number of dying } \\
\text { individuals }(\mathrm{dx})\end{array}$ & $\begin{array}{c}\text { Rate of } \\
\text { mortality(qx) }\end{array}$ & $\begin{array}{c}\text { Relative number } \\
\left.\text { of survivors( } 1 \mathrm{x}^{\prime}\right)\end{array}$ \\
\hline Eggs & 674 & 238 & 35.3 & 100.0 \\
Larvae & 436 & 170 & 39.0 & 64.7 \\
Pupae & 266 & 5 & 1.9 & 39.5 \\
Workers $(\mathrm{x})$ & & & & \\
$0-5$ & 261 & 42 & 17.9 & 38.8 \\
$6-10$ & 219 & 8 & 3.7 & 36.3 \\
$11-15$ & 211 & 6 & 2.8 & 34.9 \\
$16-20$ & 205 & 17 & 8.3 & 34.0 \\
$21-25$ & 188 & 31 & 16.5 & 31.1 \\
$26-30$ & 157 & 44 & 28.0 & 26.0 \\
$31-35$ & 113 & 36 & 31.9 & 18.7 \\
$36-40$ & 77 & 6 & 7.8 & 12.8 \\
$41-45$ & 71 & 6 & 8.5 & 11.8 \\
$46-50$ & 65 & 3 & 4.6 & 10.8 \\
$51-55$ & 62 & 3 & 4.8 & 10.3 \\
$56-60$ & 59 & 3 & 5.1 & 9.8 \\
$61-65$ & 56 & 0 & 0.0 & 9.3 \\
$66-70$ & 56 & 4 & 7.1 & 9.3 \\
$71-75$ & 52 & 10 & 19.2 & 8.6 \\
$76-80$ & 42 & 29 & 69.0 & 7.0 \\
$81-85$ & 13 & 12 & 92.3 & 2.2 \\
$86-90$ & 1 & 0 & 0.0 & 0.2 \\
$91-95$ & 1 & 0 & 100.0 & 0.2 \\
$96-100$ & 0 & & 0.0 & 0.0 \\
\hline & & 0 & &
\end{tabular}

number of cells of 102.9 and 177.0 (Gobbi et al. 1993), respectively. The number of cells produced by $P$. simillimus is much greater (391.3 cells), but it reutilize the comb cells only for the 2nd generation (Gobbi et al. 1993). The nest utilization strategy of $P$. lanio lanio is very different than other species. It builds large and polydomic nests (259.6 cells, so that each comb contain 101.3 cells) and reutilize the comb cells for up to fíve generations (Giannotti \& Machado 1994c).

Colonies of $P$. cinerascens produced a mean of 94.2 adults, 0.5 cells/day, 0.3 adults/ day, and 0.8 adults/cell (Table 1). Most of these values were smaller than that verified for $P$. versicolor colonies (Gobbi \& Zucchi 1985): 148.3 adults, 1.4 cells/day, 0.9 adults/day, and only the ratio 0.6 adults/cell was higher in $P$. cinerascens. These data suggest that colonies of $P$. versicolor are more productive than $P$. cinerascens.

Eggs of $P$. cinerascens are white, slightly curved and narrowed at the base. Egg size is $1.9 \pm 0.2 \mathrm{~mm}$ in length and $0.8 \pm 0.1 \mathrm{~mm}$ at the widest point. Five larval instars were determined and the average width of the cephalic capsules have the following values: 1 st instar $0.8 \pm 0.1 \mathrm{~mm}, 2$ nd instar $1.2 \pm 0.1 \mathrm{~mm}, 3 \mathrm{rd}$ instar $1.6 \pm 0.1 \mathrm{~mm}$, 4th instar $2.0 \pm 0.1 \mathrm{~mm}$, and 5th instar $2.7 \pm 0.1 \mathrm{~mm}$. The mean growing rate of 


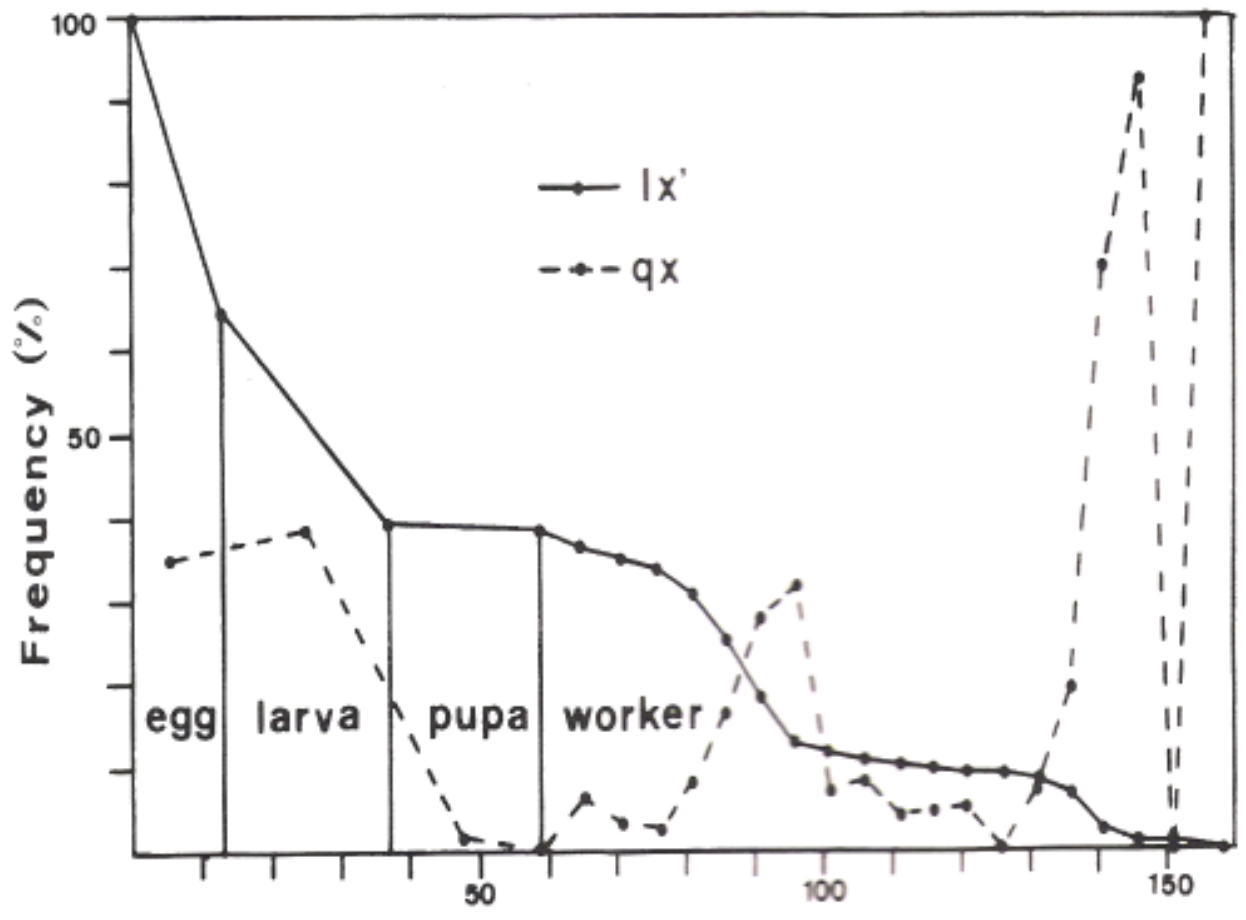

Age in days

Figure 1 - Survivorship (lx') and rate of mortality (qx) curves of immature stages and workers of Polistes cinerascens.

larvae was 1.34 , in agreement to the Dyar's rule. The width of the pupal head was $3.6 \pm 0.1$ $\mathrm{mm}$. The duration of the immature stages had the following average times: eggs $13.0 \pm 2.8$ days $(\mathrm{n}=252)$, larvae $23.7 \pm 4.2$ days $(\mathrm{n}=161)$, and pupae $22.2 \pm 3.4$ days $(\mathrm{n}=196)$. The total duration, from egg to adult, was $58.6 \pm 5.6$ days $(n=79)$. The duration of immature stages for other Neotropical species of Polistes are:

P. erytrocephaius Latreille egg 17.1, larva 26,6, pupa 23.8, total 67.5 days (West-Eberhard 1969), P. versicolor egg 10.0, larva 20.9, pupa 18.4 , and total 49.4 days (N. Gobbi personal information), P. lanio lanio egg 20.8, larva
40.6, pupa 22.6, and total 87.3 days (Giannotti \& Machado 1994a), and P. simillimus egg 10.2, larva 25.3, pupa 18.7, and total 51.9 days (E. Giannotti, unpublished data). These data suggest that besides some ecological features like local climate, food available, foraging efficiency, predator and parasitoid occurrences, which could affect every immature stage development, the pupal stage is very similar in all this Neotropical species.

The lifespan of 261 workers of $P$. cinerascens was $38.3 \pm 24.5$ days $(1-94)$. Data on the average longevity of subordinate females in some Polistes species range from 10 to 60 
days, and it could vary among colonies, according to local temperature, and method of observation. The life-span of workers of the Neotropical wasp $P$. versicolor varied from 10.8 to 17.6 days in four colonies (N. Gobbi personal information), of $P$. lanio lanio from 22.3 to 44.7 in 8 colonies (mean 28.3 days) (Giannotti \& Machado 1994b), and the average longevity of workers of $P$. simillimus was 29.1 days (E. Giannotti, unpublished data).

The life table (Table 2) and the survivorship curve (Fig. 1) of immatures and adults of $P$. cinerascens showed a rate of mortality of 35.3 for the egg stage, 39.0 for larval stage and only 1.9 for pupal stage. Oophagic behaviors are performed by the adults either to maintain their hierarchical position (differential oophagy), eating the eggs newly laid by the other nest mates, or for nourishment (nutritional oophagy) (Gervet 1964). Main cause of larval losses in social wasps is the larviphagy, that generally occurs under unfavorable climatic conditions as a form to substitute the foraging activity of the workers. Eggs and larvae in the peripheries of the comb cells are eaten rather than those in the center of the comb. Because of this high oophagy and larviphagy rates the percentage of productive cells of $P$. cinerascens was only 55.2 (Table 1 ). Main cause of the small pupal losses was the parasitism by an Ichneumonidae wasp, observed only in the Colony 7 .

The life table for workers of $P$. cinerascens (Table 2 and Fig. 1) showed high rates of mortality at the first age interval (0-5 days) and from 21 to 35 days (near to the average longevity of these wasps 38.3 days). Most of the adult population (70.5\%) was dead until the 31-35 days age interval. This was also observed in the life table of $P$. lanio lanio workers. Nevertheless, workers of $P$. lanio lanio did not forage in the first age interval (Giannotti \& Machado 1994b). The increasing in the mortality rate along the age intervals generally coincide with the starting of the foraging activity of the wasps and consequent exposure to the predation or the inclemency of climatological conditions, besides the physical wasting of the forager. On the other hand, some long-lived wasps observed in the life table were the highest females in the social hierarchy of the colonies, but below to the queen. Some of them were experienced foragers but others were non-foragers that performed only intranidal tasks, as observed by Giannotti \& Machado (1994b) in P. lanio lanio.

\section{Acknowledgments}

I am grateful to Dr. Maria F. Manzoli-Palma for collecting colony 4 and to Dr. Sulene N. Shima for critical reading the manuscript.

\section{References Cited}

Gervet, J. 1964. Le comportement d'oophagie différentielle chez Polistes gailicus L. (Hymen.Vesp.). Ins. Soc. 11: 769-798.

Giannotti, E. \& V.L.L. Machado. 1994a. The seasonal variation of brood stages duration of Polistes lanio (Fabricius, 1775) (Hymenoptera, Vespidae). Naturalia 19: 97-102.

Giannotti, E. \& V. L. L. Machado. 1994b. Longevity, life table and age polyethism in Polistes lanio lanio (Hymenoptera:

Vespidae), a primitive eusocial wasp. J. Adv.Zool. 15:95-101.

Giannotti, E. \& V.L.L. Machado. 1994c. Colonial phenology of Polistes lanio lanio (Fabricius, 1775) (Hymenoptera, Vespidae). Rev. Bras. Entomol. 38: 639643.

Giannotti, E. \& C. B. Mansur. 1993. Dispersion and foundation of new colonies in Polistes versicolor (Hymenoptera, Vespidae). An. Soc. Entomol. Brasil 22:307-316.

Gobbi, N. \& D. Simões. 1988. Contribuição ao entendimento do ciclo básico de colô- 
nias de Mischocyttarus (Monocyttarus) cassununga von Ihering, 1903 (Hymenoptera, Vespidae). An. Soce. Entomol. Brasil 17:421-436.

Gobbi, N. \& R. Zucchi. 1980. On the ecology of Polistes versicolor versicolor (Olivier) in southern Brazil (Hymenoptera, Vespidae, Polistini). I. Phenological account. Naturalia5:97-104.

Gobbi, N. \& R. Zucchi. 1985. On the ecology of Polistes versicolor versicolor (Olivier) in southern Brazil (Hymenoptera, Vespidae, Polistini). II. Colonial productivity. Naturalia 10:21-25.

Gobbi, N., H.G. Fowler, J. Chaud-Netto \& S.L. Nazareth. 1993. Comparative colony productivity of Polistes simillimus and Polistes versicolor (Hymenoptera: Vespidae) and the evolution of paragyny in the Polistinae. Zool. Jb. Physiol. 97:239-243.

Jeanne, R.L. 1972. Social biology of the Neotropical wasp Mischocyttarus drewseni Bull. Mus. Comp. Zool. 144: 63-150.

klalin, J. E. 1979. Philopatric and nonphilopatric foundress associations in the social wasp Polistes fuscatus. Behav. Ecol Sociobiol.5:417-424.

Pfenning, D.W., G.J. Gamboa, H.K. Reeve, J. Shellman-Reeve \&T.D. Ferguson. 1983. The mechanism of nestmate discrimination in social wasp (Polistes, Hymenoptera: Vespidae). Behav. Ecol. Sociobiol. 13:299-305.

Post, D.C. \& R.L. Jeanne. 1982. Recognition off former nestmates during colony foun- ding by the social wasp Polistes fuscatus (Hymenoptera: Vespidae). Behav. Ecol. Sociobiol. 11:283-285.

Reeve, H.K. 1991. Polistes, p. 99-148. In K.G. Ross \& R.W. Mattews (eds.), The social biology of wasps. Ithaca, Comell University Press, 678 p.

Richards, O.W. 1978. The social wasps of the Americas excluding the Vespinae. London, British Museum (Nat. Hist), 580 p.

Shellmann, J.S. \& G.J. Gamboa. 1982. - Nestmate discrimination in social wasps: the role of exposure to nest and nestmates (Polistes fuscatus, Hymenoptera: Vespidae). Behav. Ecol. Sociobiol. 11: 51-53.

Silveira-Neto, S., O. Nakano, D. Barbin \& N. A. Vilanova. 1976. Manual de ecologia dos insetos. São Paulo, Ceres. 519 p.

Simões, D. \& M.R. Mecchi. 1983. Estudo sobre a fenologia de Polybia (Myrapetra) paulistaIhering, 1896 (Hymenoptera, Vespidae). Naturalia 8:185-191.

West-Eberhard, MJ. 1969. The social biology of Polistine wasps. Misc. Publ. Mus. Zool. Univ.Mich. 140: 1-101.

Yamane, S. 1986. The colony cycle of the Sumatran paper wasp Ropalidia (Icariola) variegata jacobsoni (Buisson), with reference to the possible occurrence of serial polygyny. Monitore zool. ital. (N.S.) 20:135-161.

Received 29/1/96. Accepted 21/1/97. 